\title{
APPLIED ETHICS IN THE OTTOMAN LEGAL SYSTEM IN THE BALKANS: A CASE STUDY OF BITOLA (MACEDONIA) WITH REFERENCE TO THE SIJILLĀT AL-SHAR 'TYYAH
}

\section{Mesut Idriz*}

\begin{abstract}
After the Ottoman withdrawal, numerous researchers of the Balkan peoples evaluated centuries of Ottoman domination in a negative and often hostile manner by interpreting it in a nationalistic and often myopic view. Based on archival materials left by the Ottomans, it has become incumbent upon the students to investigate and analyze as objectively as possible the history of Ottoman rule and its legal system in this region. Among all the documents contained in the archives those of the Sijillat al-Shar iyyah (Islamic Judicial Records) are considered to be the most important, where in them the reliable objective case-by-case sources are found, not only in legal aspects but also in socio-economic matters and religiocultural institutions related to both Muslims and non-Muslims. In recent decades, the notion of "Applied Sharī'ah and Ethics" has been used in a loose manner without a real and proper definition, mostly in matters related to the legality of contemporary business transactions. This article will attempt to discuss and present the correct meaning of applied Sharīah and ethical approach by claiming that the most remarkable sources are the recorded documents preserved in the Sharīah courts. In order to do so, the article focuses on two combined points: the Ottoman judicial records and a case study of the famous Balkan region of Ottoman Bitola (formerly known as Manastir) in Macedonia, where the former archival documents are found. Bitola is chosen as a model for how the Islamic laws were applied during the dominance of Ottoman Empire in the territory. It is well-known that the region of Bitola was a melting pot and a mosaic of various ethnic groups mainly Greeks, Turks, and Albanians, with different religious beliefs comprising of Muslims, Christians and Jews.
\end{abstract}

Keywords: environmental ethics, shari'ah law, Balkans, Ottoman legal system.

Professor of Comparative History of Civilizations, Law and Ethics, and Political Science courses at the International University of Sarajevo. 


\title{
ETIKA GUNAAN DALAM SISTEM UNDANG-UNDANG UTHMANIYYAH DI NEGARA-NEGARA BALKAN: KES BITOLA (MACEDONIA) DENGAN MERUJUK KEPADA SIJILLAT AL-SHAR IYYAH
}

\begin{abstract}
ABSTRAK
Setelah penarikan balik kuasa Uthmaniah, ramai penyelidik dari Balkan menilai penguasaan Kerajaan Uthmaniyyah sebagai sesuatu yang negative dan bersifat bermusuhan. Ini berlaku kerana penilaian tersebut selalunya dibuat berdasarkan perasaan cintakan negara bangsa mereka. Berdasarkan maklumat peninggalan Kerajaan Uthmaniyyah, ianya menjadi tanggungjawab kepada pelajar untuk menyelidiki dan menganalisa secara objektif mengenai sejarah pemerintahan Kerajaan Uthmaniyyah dan sistem undang-undang yang digunakan di rantau ini. Antara dokumen-dokumen yang di tinggalkan ialah Sijillat al-Shari'iyyah (Rekod Penghakiman Islam) yang dianggap sangat penting kerana ia membolehkan penyelidikan dilakukan keatas kes-kes secara berasingan. Ini membolehkan kajian terperinci dilakukan keatas bukan sahaja sistem undangundang tetapi juga membolehkan penyelidikan di lakukan keatas keadaan sosio-ekonomi dan juga institusi kebudayaan dan agama yang berkait rapat dengan orang-orang Islam dan bukan Islam pada masa itu. Dalam era baru ini, terdapat tanggapan bahawa terma, "Etika dan Shariah Gunaan" hanya boleh digunakan untuk perkaraperkara yang berkaitan dengan kesahan perniagaan masa kini. Oleh itu, terma tersebut masih belum mempunayai defines yang sebenar. Makalah ini akan membincangkan dan mengenengahkan maksud sebenar Shari'ah dan etika gunaan dengan berlandaskan sumber yang jitu iaitu rekod-rekod yang dipelihara oleh penghakimanpenghakiman Mahkamah Shariah. Makalah ini tertumpu pada dua terma pokok iaitu: rekod penghakiman di zaman pemerintahan Uthmaniyyah dan kawasan Balkan yang terkenal di zaman itu iaitu Bitola (dulu dikenali sebagai Manastir) di Macedonia, di mana dokumen-dokumen ini di jumpai. Bitola telah di pilih sebagai model bagi pemakaian undang-undang Islam ketika zaman pemerintahan Uthmaniyyah. Bitola merupakan kawasan yang di ketahui menjadi wadah tumpuan pelbagai bangsa, antaranya Yunani, Turki dan Albania, di mana kesemua mereka juga berbilang agama seperti Islam dan bukan Islam.
\end{abstract}

Kata Kunci: etika persekitaraan, undang-undang shari'ah, sejarah balkan, sistem undang-undang uthmaniyyah 


\section{INTRODUCTION}

Ottoman state and its applied rules and regulated laws concerning society in dealings among humans and between human-nature relations are considered highly significant subject for a worldly empire that stretched from Indic world to the Balkans in Europe and Morocco in North Africa which its existence lasted for the period of over a half millennium. Undoubtedly, this great Muslim state paid immense attention to the contextual and conceptual meaning of environment as well as its application in the concerned society. Taking into consideration the ethical and legal aspects, the Ottoman rulers and governors issued various decrees; scholars compiled many treatises; established offices and institutions in applying the laws, educating communities, issuing summons, and other related matters, as it will be elaborated in this paper, regarding the ethical dimension of environment and its awareness. Besides Qur'anic verses and the Prophetic approach, this consciousness is clearly indicated in the works such as Kinalizade Ali Efendi's Akhlaq-i 'Alai (The Highest Ethics), who authored the book during the first half of the $16^{\text {th }}$ century, whereby it deals greatly on the universal issues concerning politics, ethics and environment. We may find large number of fatwa compilations by the Ottoman scholars in this regard; among them is Shaykh al-Islam Ebu Es-Su'ud Efendi's Fatawa-i Ebu Es-Su'ud, who is very well known as strict environmentalist. ${ }^{1}$ Ethics and environmental subjects are also found in the works of Divan poetry. ${ }^{2}$ These are just few examples from the theoretical point of view.

However, practical aspects of environmental ethics during the Ottoman era are found mainly in the following four sources: 1) Fermans of the Ottoman Sultan issued to and ordered for the adherence by the high ranking governors and regional officers; 2) Qadis' compilation of judicial records called Şer'iyye Sicilleri (Sijillat al-Shar'iyyah), in which we are going to give a glimpse on this source later and we will be basing our argument and discussion mainly by

$1 \quad$ It is recommended that Ebu Es-Su'ud Efendi's fatwas should be studied and examined by contemporary scholars as it has yet to be explored and understood well his contributions in the area which we are concerned in this paper.

2 For a comprehensive work in this, see M. Necat Sefercioglu, Divan şiirinde

Çevre [Environment in Divan Poetry], at http://turkoloji.cu.edu.tr/ESKI\%20TURK\%20\%20EDEBIYATI/nejat_seferciog1 u_divan_siirinde_cevre.pdf (Accessed on 24.02.2015) 
referring to this important source; 3) Waqf deeds related directly or indirectly to the subject of ethic and environment; and 4) Muslim and non-Muslim Travelers Accounts who visited the Ottoman lands and described the environment of cities/towns/villages, architectural monuments, urban and rural dwellers and their approach towards the environmental ethics. ${ }^{3}$ With the exception of the last one, the former three sources are found in different archives which remained and preserved from the Ottoman period, and it is estimated that this could be over a hundred million documents, though not all of them are kept in Turkey but in various countries that were under the Ottoman dominion throughout the Balkans, Middle East and North African regions. Being multiracial, multiethnic and multi-religious Empire covering significant parts of the meeting point of three continents of Euro-Afro-Asia, it was necessary for the Ottomans to think seriously about the environment and from time to time regulate the laws related to it.

The major objective of this paper is to provide historic-legal information and contribute towards the understanding of values and attitudes of the societies in relation between human being and environment in the Muslim Ottoman Empire. It is very difficult, of course, to deal and discuss this subject in general scope as we stated that the Ottoman Empire covered wide geography and existed for a long period of time; however, we will limit our self to the Balkans and particularly to the major administrative district (sancak or later vilayet) of Bitola (Manastir), which covered present-day Macedonia, Albanian and North Greece regions. It is useful to mention here that this area was the longest serving region of the Ottomans, where it was conquered immediately after the establishment of the Empire and dissolved by the dissolution of the Empire. It is believed that the reason behind this is that the whole region fall in line with the old Roman highway namely Via Egnatia, which served for more than two millenniums as the major route connecting the Silk Road in Istanbul and Europe via Rome. As a matter of fact, it attracted settlers of various races, ethnicities and religions of the world.

For detailed study, see Mesut Idriz, The Balkan City of Ottoman Manastir, (Kuala Lumpur: Pelanduk, 2010), and Ibrahim Ozdemir, "Osmanli Toplumunda Cevre Anlayisi", in Turkler ed. by H. C. Guzel and K. Cicek (Ankara: Yeni Turkiye Yayinlari, 2008), vol. 10, 598-610. 
However, before proceeding with this subject, we should briefly touch upon the material source of Qadi's judicial records, its meaning and definition in order to have a clear picture of the content.

\section{QADI'S JUDICIAL RECORDS: MEANING AND DEFINITION}

Sijillat al-Shar'iyyah or Qādi Sijils of the Ottoman Empire were books compiled at law courts throughout the empire. Although this sort of book antedates the Ottoman period in Muslim history, however, the only books known to have survived to the present day were compiled in Ottoman courts. ${ }^{4}$ The Sijillat al-Shar'iyyah were local court record books generally written in single handwritten copies. After compilation, they were preserved at many sites in courts, used and consulted for reference occasionally over one or two generations. ${ }^{5}$ They were preserved locally, where some were stolen or destroyed in wars, while others were burned or became rotten from exposure. ${ }^{6}$ These judicial records contain various types of documents, which generally are of two kinds: 1) those that were issued by the $Q \bar{a} d \bar{l}$ himself; and 2) those issued by other authorities and recorded in the sijil by the $Q \bar{a} d \bar{l}$. The documents belonging to the first kind usually cover the largest portion of each sijil. Among those that belong to this kind are mainly hüccets, i'lâms, and murâseles. Hüccets are all kinds of evidences, testimonies, or proof letters issued by a $Q \bar{a} d \bar{l}$ on various legal cases such as marriage, divorce, guardianship, contracts of buying and selling, charter of the endowments (waqfiyyah, vakfiye), and others. I'lâms are all kinds of decisions carried out according to the judgments of the $Q \bar{a} d \bar{l}$ on various issues such as debt, theft, adultery, punishment, and so on. Murâseles are all official correspondence on various matters between

4 Galal H. El-Nahal, The Judicial Administration of Ottoman Egypt in the Seventeenth Century, (Minneapolis \& Chicago: Bibliotheca Islamica, 1979), 1.

See Mesut Idriz, The Balkan City of Ottoman Manastir, 10-12.

6 For instance, here are given two such examples of burn and steal, first a fire in 1884 burned all the sijils preserved in Beypazarı, an important town on the caravan route from Ankara to Istanbul, and second in 1580 the $Q \bar{a} d \bar{\imath}$ of Anduğ , a place near Niğde, took to flight with 40-50 sijils in an attempt to conceal a series of crimes he committed. The documents for both examples are set forth by Halit Ongan, Ankara'nın 1 Numaralı Ser'iye Sicili, (Ankara: Türk Tarih Kurumu Basımevi, 1958), viii-ix. 
a $Q \bar{a} d \bar{l}$ and officials under his authority. ${ }^{7}$ The documents of the second kind usually cover the minor portion of each $Q \bar{a} d \bar{\imath}$ Sijil, and among those that fall under this kind are mainly fermâns and emîrs, berâts, buyuruldis, tezkeres and temessuks. Fermâns and emîrs are various decrees, orders, policies and regulations issued directly from the Porte by the sultan on various matters, which were addressed to all high-ranking officials including the $Q \bar{a} d \bar{\imath} \mathrm{s}$. Berâts are imperial patents to fill certain positions, such as $q \bar{a} d \bar{l}$, imām and mutawalli (mutevelî), which were also issued by the Porte. Buyuruldîs are orders issued by the Sadrazams (Grand Viziers), Beylerbeys (Governors) and Kazaskers (high-ranking military judges) on matters that were addressed to the $Q \bar{a} d \bar{l}$ and other government officials. Tezkeres and temessuks are important correspondences and legal documents issued by the lower administrative officials and others, which were recorded in the Sijils. ${ }^{8}$

After this brief account of the judicial records and their content, the question of the significance of these books can now be raised. Scholars and historians are unanimous that among other sources on Ottoman history, the court records undoubtedly play an important role to the extent that they are considered the primary sources. ${ }^{9}$ However, most Ottoman historians have only had a cursory familiarity with these judicial records. A few historians have read them looking for particular kinds of documents, such as imperial orders, or materials related to the relation between Muslims and non-Muslims, or local traditions. ${ }^{10}$ Until recently no systematic study of these records has ever been undertaken, with the exception of a few studies dealing

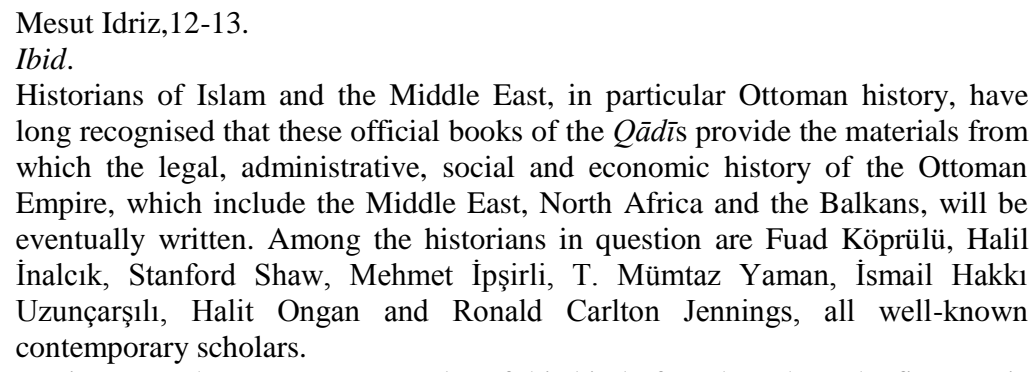

Historians of Islam and the Middle East, in particular Ottoman history, have long recognised that these official books of the $Q \bar{a} d \bar{l}$ s provide the materials from which the legal, administrative, social and economic history of the Ottoman Empire, which include the Middle East, North Africa and the Balkans, will be eventually written. Among the historians in question are Fuad Köprülü, Halil İnalcık, Stanford Shaw, Mehmet İpşirli, T. Mümtaz Yaman, İsmail Hakkı Uzunçarş1l1, Halit Ongan and Ronald Carlton Jennings, all well-known contemporary scholars.

10 For instance, there are two examples of this kind of works, where the first one is pertinent article on the waqfs of Ankara by Halit Ongan, "Ankara Şer'iye Mahkemesi Sicillerinde Kayitlı Vakfiyeler", in Vakıflar Dergisi, 5 (1963), 213223; and work on the conversions (ihtidâ) in Bursa by Osman Çetin, Sicillere Göre Bursa'da İhtida Hareketleri ve Sosyal Sonuçları (1472-1909), (Ankara: Türk Tarih Kurumu Basımevi, 1994). 
only with a particular city or region. ${ }^{11}$ Similarly, some local historians in several Turkish cities have read the judicial records of their cities extensively and have even published transliterations and summaries of interesting books. However, although few historians have had an understanding of the old judicial procedure, yet in general they lack the formal training necessary to use the sijils effectively as sources for administrative, legal, social, and economic history. ${ }^{12}$

Although thousands of these records survive to the present day, any attempt to determine precisely what survives where is premature. As stated earlier, most of them are kept in the archives, or museums, or other places in both Muslim and non-Muslim countries. In Europe, with a few exceptions, the surviving number of Sijillat al-Shar'iyyah date from the later period of the Ottoman Empire, after the long series of Ottoman defeats in the last quarter of the $17^{\text {th }}$ century. In the Balkans, an almost complete list of those surviving in Bulgaria have been published; ${ }^{13}$ Two judicial records survive from Hungary; ${ }^{14}$ an important and large collection survives from Bosnia, Macedonia and Greece; and a very few other judicial records survive from several of the Southeastern European countries. ${ }^{15}$

As far as the Arab world is concerned, formerly part of the Ottoman Empire, there are many surviving Sijillat al-Shar'iyyah belonging to different countries. Almost two thousand are preserved in Egypt at the Court of Personal Status in Cairo. ${ }^{16}$ The surviving numbers of judicial records in Israel are those of Jaffa and Jerusalem,

11 See Ronald C. Jennings, The Judicial Registers (Şer'i Mahkeme Sicilleri) of Kayseri (1590-1630) as a Source for Ottoman History, A Ph.D. Dissertation, (Michigan: UMI, 1985); and Rifat Özdemir, XIX. Yüzyılın ilk yarısında Ankara, 2nd reprint, (Ankara: Türk Tarihi Kurumu Basimevi, 1998).

12 Besides the $q \bar{a} d \bar{\imath}$ sijils, there is also the lack of the formal training necessary to use the Ottoman archival documents in general. See Halil Inalcik, "The Turks and the Balkans", Turkish Review of Balkan Studies, 1 (1993), Istanbul, 38-39.

13 For instance, see Galab Galabov, Die Protokollbücher des Kadiamtes Sofia, trans. By H. Duda, (Munich, 1960); and J. Kabrda, "Les registres turcs des cadis de Sofia et de Vidin et leur importance pour l'histoire de le Bulgarie", in Archiv Orientalni, 19 (1951).

14 One belongs to Temesvar (1651-1653) and the other to Karansebes and Lugos (1673-1675). See Klara Hegyi, "The Terminology of the Ottoman-Turkish Judicial Documents on the Basis of the Sources from Hungary", in Acta Orientalia, 18 (1965), 191.

15 Mesut Idriz,. 15-17.

16 For the sijils of Egypt see the work of Stanford J. Shaw, "Cairo's Archives and the History of Ottoman Egypt", Report on Current Research, Spring 1956, (Washington: Middle East Institute, 1956). 
where the former ones date back to the period of Napoleon. ${ }^{17}$ Jon Mandaville has surveyed the sijils of Jerusalem, Damascus, Aleppo, Homs, and Hamah, but has given no indication as to whether any may still survive in the other cities of Syria, Jordan and Lebanon. ${ }^{18} \mathrm{He}$ has been informed that records exist from Baghdad and Basra. ${ }^{19}$ The judicial sijils dating from about the time of the Ottoman conquest also exist in Cyprus, ${ }^{20}$ and the Northern African countries. ${ }^{21}$ There must be $Q \bar{a} d \bar{l}$ records from cities of the Arabian Peninsula namely Makkah (Mecca), Madinnah (Medina), and elsewhere, and it would be also possible that court records are available from the Georgian and Armenian areas of the Caucasus, but no mention appears in the standard article materials on Ottoman history.

Some earlier Muslim courts considered the sijils to be the property of the $Q \bar{a} d \bar{l}$, to be left in his possession, an arrangement that may have been adequate for a judicial system in which $Q \bar{a} d \bar{l}$ s were notable local members of the council of 'ulamā' who served for long periods of time, and in which evidence of the written word was not held in high esteem. However, the situation in the Ottoman Empire was different, where the $Q \bar{a} d \bar{l}$ judicial records were preserved locally and were never sent to the Porte. For instance, the judicial records in the Balkan region were preserved by the court locally.

In Southern Balkans, namely the region which is under study in this paper, i.e. Bitola, there is more than two hundred Sijillat alShar'iyyah dating from the beginning of the $17^{\text {th }}$ century until the beginning of the $20^{\text {th }}$ century. Before the Second World War they were housed at the Vakıf Library (Vakufska Biblioteka) in Bitola. After the war they were transferred to their present location in the Macedonian State Archives in Skopje (the capital of the Republic of

17 Jon E. Mandaville, "The Ottoman Court Records of Syria and Jordan", Journal of the American Oriental Society, 86 (1966), 313.

18 Ibid.,315-318.

19 This claim is cited in R. C. Jennings, The Judicial Registers (Şer'i Mahkeme Sicilleri) of Kayseri (1590-1630) as a Source for Ottoman History, Unpublished Ph.D. Dissertation, 24.

20 See Ronald C. Jennings, Christians and Muslims in Ottoman Cyprus and the Mediterranean World (1571-1640), (New York: New York University Press, 1993), where the work is based mostly on the $q \bar{a} d \bar{l}$ sijils of Cyprus.

21 Among the works on North African countries see Jacques Berque, "Petits documents d'histoire sociale marocaine: Les archives d'un cadi rural", Revue Asiatique, (1950), 113-124. 
Macedonia) where they now represent the principal holdings remaining from the Ottoman period.

\section{APPLIED ENVIRONMENTAL ETHICS IN THE REGION OF BITOLA OF THE BALKANS}

After giving an illustration on the meaning of Sijillat al-Shar'iyyah and their content, we shall proceed with the subject of applied environmental ethics in the region of Bitola of the Balkans where we will principally base our discussion with reference to the Qadi's judicial records. The documents pertaining to the matter of our interest covers a large area of socio-economic and legaladministrative issues. In order to be systematic in our study, we are going to focus to the two very significant interrelated areas of the Ottoman legal system with reference to the Balkans: first is the function of the Muslim institution of Hisbah and its chief officer the Muhtasib; and followed by the implementation of the tradition of narkh. Both elements have direct relations with the problem of ethics and environment, whereby they deal with the great instance on various issues concerning human being and nature relations. These two areas of study and practice, as will be seen below, put the universal ethical principles in relation to the environment, which could shed light on the Muslim past, teach the present day practitioners and imagine the better future for mankind.

Nevertheless, before giving further elaboration on these two issues, we shall briefly cite some examples whereby the Ottoman Sultan sent his fermans (decrees) to the regional Qadi of Bitola related to the issues concerning ethical orders and actions to be taken by the Qadi. The imperial correspondences addressed to the Qādīs of Bitola are all found in the judicial records, insofar as they survive. The followings are summaries of two such correspondences: ${ }^{22}$

To the Qādīs of Manastir, Kesriye, Dirame(Drama), Sari-Göl, Florina, and other officials [of Bitola Region]: Know that you have delayed making the necessary arrangements to transport food and other necessary items by animal train to the Porte. Urgency requires

22 Archival sources of Bitola Judicial Records are cited as follows: e.g. Sijil: \#542a-3, meaning Manastir $q \bar{a} d \bar{\imath}$ sijil (judicial record book) number 54, page 2a, entry 3 . 
that you take immediate action. I expect my orders to be carried out immediately without further delay. Issued on the $9^{\text {th }}$ Rabī ulevvel, 1192 A.H. $^{23}$

Regarding the timâr [fiefdom] ${ }^{24}$ from the villages of Bistriçe and others from the nâhiye of Manastir [Bitola Region] in the amount of 6962 akçes, which belonged to the brothers Ismail and Mahmud, sons of Ibrahim. Ismail b. Ibrahim made a petition to the Porte [Sultan] that his brother Mahmud produced a false berât claiming that the timâr in question belonged to him. Mahmud's claim was examined and many officials bore witness that his berât was deception. As a result, the Porte issued a fermân in the year 1191 A.H. dismissing Mahmud and re-appointing Ismail as the timâr of these villages. But the $Q \bar{a} d \bar{l}$ of Manastir had to investigate the matter and take legal action against Mahmud. ${ }^{25}$

Sometime the Qadi of Bitola wrote petition to the Sultan or Imperial Palace informing on the environmental matters or problems. For example:

To the Porte: For the sake of the protection of sheep and other animals from bandits and thieves, it has been suggested, by the representatives of the people to employ several people as protectors. We have already appointed 40 people in total for this position from different villages. We hope Your Excellency approves and issues a fermān regarding this matter. Recorded in the middle of Şevvâl,

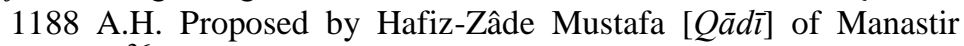
[Bitola]. ${ }^{26}$

Having given some examples of the correspondences between the Qadi of Bitola and the Ottoman Sultan at the Porte, we shall continue first with the institution of Hisbah and its scope provided with examples from the judicial records of Bitola, and then followed by the practice of a highly important tradition of narkh system.

\footnotetext{
23 Sijil: \#62-15b-1.

24 A timar was land granted by the Ottoman Sultans to certain distinguished people called Timariot.

25 Sijil: \#62-12b-1.

26 Sijil: \#60-63a-3.
} 


\section{The Institution of Hisbah and The Narkh System}

The institution of Hisbah and its officer Muhtasib in the early Islamic tradition was a person of immense power, a "police chief", patroller of bazaars, and guardian of public morals. According to al-Māwardī, the Muhtasib had jurisdiction exceeding that of the $Q \bar{a} d \bar{l}$. This meant that a Muhtasib could investigate a suspicious matter even when no complaint had been lodged and that he had the power to suppress wrongdoing $\left(t^{\prime} z \bar{z} \mathbf{r}\right)$. However a Muhtasib could not consider any matter not involving a wrongful act, this was left to the domain of a $Q \bar{a} d \bar{l}$ alone, a Muhtasib's jurisdiction was restricted only to matters where a confession or admission has been made. ${ }^{27}$ During the earlier periods of Islam, apart from patrolling bazaars and controlling prices in the market, the office of Muhtasib was also guardian of public morals, based on the Islamic rule "al-amr bi'l-ma 'rüf wa al-nahyi 'an al-munkar" (enjoining good and forbidding evil). A Muhtasib was an officer with many duties, part of which involved ensuring public order and ensuring that religious rules are adhered to accordingly. Later on, in particular during the Ottoman Empire, the office of Muhtasib was limited only to controlling bazaars and market prices. In addition, he was among the primary assistants to the $Q \bar{a} d \bar{l}$, his position was not autonomous unlike, as can be the earlier periods of Islam where from-time-to-time he could issue a warning and even criticize the $Q \bar{a} d \bar{\imath}$. A Muhtasib acting on the orders of the $Q \bar{a} d \bar{\imath}$ had to control and inspect the products in the market in general. In addition, he had to make sure there was no monopoly or black marketers, to inspect guilds, weights and measures, to control quality and cleanliness, and to charge the unscrupulous with court action. ${ }^{28}$

It is worth mentioning, the Ottoman Muhtasibs of Bitola fulfilled only the duties of the marketplace, not those related to morality. They did not deal with hardcore criminal investigations of any sort-such powers belonged to the offices of the $Q \bar{a} d \bar{l}$ directly. The Muhtasib did not bring people to court for matters outside the scope of the bazaar and the products of all kind. ${ }^{29}$ Any prosecution requested by him

27 Abu'l-Hasan Al-Māwardī, Al-Ahkām al-Sultāniya: The Laws of Islamic Governance, trans. by Asadullah Yate, (London: Ta-Ha Publishers, 1996), 337 362.

28 R. Levy, "Muhtesib", Islam Ansiklopedisi, vol.: 8, 532.

29 It is noteworthy that Uriel Heyd found the muhtasib in the $15^{\text {th }}$ and $16^{\text {th }}$ centuries used for investigating many of the criminal cases and bringing criminals to court 
involved business practices using faulty weights and measures, violations of the consumers' norms, causing obstructions and disorder, public complaints in the protection of nature and the public goods, or all sorts of cases related to the market place. For example, "the Muhtasib Yusuf brought the bakers of Bitola (Manastir), Mustafa, Kasim, Peyo, Todor, Ahmed, Haso and others, to court. They had refused to sell bread to the public and as a result many complained. The Muhtasib asked the court to punish them if the bakers continued to be defiant." $" 30$

Those who were sincere and pious were suited for the office and were appointed as Muhtasibs by the Qādi of Bitola. To be a Muhtasib did not require profound knowledge of the Sharīah (Islamic law). Some of Muhtasibs were professional shopkeepers and traders. For instance, both Mehmed and Haci Ramadan were appointed Muhtasibs of Bitola, prior to which the former was a butcher while the latter a greengrocer. ${ }^{31}$

Unlike other officials, the duration of service for a Muhtasib in Bitola was on a one-year term. If there were no complaints against the Muhtasib from the public, in particular from the guilds, or if they were fully satisfied with the performance of his duties, then he was re-appointed for another term. This practice was in order to avoid from any kind of misuse of the office and involvement with any form of the corruption. For example, the Muhtasibs Yusuf, Huseyin, and Ali, after completing their one-year term; they asked the court to renew their position for another term. ${ }^{32}$ However only the $Q \bar{a} d \bar{l}$ of Bitola had the right to reject his or their reappointment to the office of

on several charges. Uriel Heyd, Studies in Old Ottoman Criminal Law, (Oxford: Oxford University Press, 1973), 232. It is interesting because it can be stated quite categorically that this finding in the later centuries, particularly during $17^{\text {th }}$ and $18^{\text {th }}$ centuries, is that the muhtasib was never used for that purpose either in Manastir or in Bursa. For more information about Bursa see Haim Gerber, State, Society, and Law in Islam: Ottoman Law in Comparative Perspective, (Albany: State University of New York, 1994), 69.

30 Sijil: \#8-15a-5; the original document is published together with its translation in Turskite Dokumenti za Istorija na Makedonskiot Narod, vol: 4, 39 and appendix 50.

31 Sijil: \#3-84a-3, the original document is published together with its translation in Turskite Dokumenti za Istorija na Makedonskiot Narod, vol: 2, 138 and appendix 259.

32 Sijil: \#2-21a-10; the original document is published together with its translation in Turskite Dokumenti za Istorija na Makedonskiot Narod, vol: 1, 130 and appendix 194. 
Muhtasib, and to dismiss or sack a Muhtasib before his term ends. For example, "the people of Bitola region, including the guilds, complained and filed litigation against the Muhtasib Yusuf bin Bayram, accusing him of drinking wine, assaulting and maltreating the guilds and customers of the bazaar. They did not want him to be the Muhtasib of Bitola (Manastir) any longer. According to the litigation, the Qadi of Bitola sacked Yusuf from office."33

The number of Muhtasibs in the region of Ottoman Bitola depended on need. Usually there were between two and five Muhtasibs at one time. For example, the Muhtasibs Bâlî, Musli, Bayram, Mehmed and Haci Ramadan, all served at the same time. ${ }^{34}$ Also the Muhtasibs Ali bin Ibrahim, Huseyin bin Huseyin and Mustafa bin Hasan served at the same time. ${ }^{35}$

The office of Muhtasib was frequently mentioned in the $Q \bar{a} d \bar{l}$ records and exclusively with regard to patrolling the bazaars. The Muhtasib's name occasionally appeared next to a listing of official fixed prices (narkh); therefore, it is necessary to clarify the meaning of narkh and its practice in the Ottoman legal system with the special focus to the Balkan region of Bitola.

The term "narkh" is Ottoman-Turkish derived from the Persian word "nirkh", meaning market prices, rates, ratios, etc. ${ }^{36}$ It is equivalent to the Arabic term "si ' $r$ " (plural: as 'âr). Technically it means the market price for certain goods and services determined by the relevant authorities. In the Ottoman Empire all sorts of goods, commodities and services were subjected to the institution of narkh. In Islamic law, all sorts of business, buying-and-selling, and trade are based on mutual agreement of both parties, buyer and seller. Based on the Hadith of the Prophet Muhammad, Allah Almighty alone knows the value of goods, and He alone can determine their value. However, in another Hadìth He explicitly forbade unjust profit. ${ }^{37}$

33 Sijil: \#3-94a-4, the original document is published together with its translation in Turskite Dokumenti za Istorija na Makedonskiot Narod, vol: 2, 143 and appendix 270.

34 Sijil: \#3, passim.

35 Sijil: \#54-5a-3.

36 F. Steingass, A Comprehensive Persian-English Dictionary, $8^{\text {th }}$ impression, (London \& New York: Routledge, 1988).

37 See the following works where in this regard few hadiths are cited: Mübahat S. Kütükoğlu, Osmanlılarda Narh Müessesesi ve 1640 Tarihli Narh Defteri, (Istanbul: Enderun Kitabevi, 1983), p. 3; and Mehmet Z. Pakalın, Osmanlı Tarih Deyimleri ve Terimleri Sözlüğ̈̈, vol.: 2, 654-655. 
Contrary to the opinion of certain jurists, who disapproved of its practice, the Ottomans considered the practice of narkh very important to the extent that it became a well-developed institution. In the opinion of the ruling class and the 'ulamā ' of the Empire the practice of narkh ensured prosperity among the people who were being ruled. Some Ottoman scholars, especially those who were engaged in theoretical aspects of many issues in the government, almost always emphasized narkh in their works, and also frequently advised government officials to be concerned with and exercise control of narkh. Amongst them, for instance, was the Grand Vizier Lütfi Paşa during the reign of Kanûnî Sultan Suleyman (the Lawgiver) (1520-1566). In his magnum opus Âsafnâme he expounded upon the subject and stressed that narkh is one of the most important issues of government, and therefore its officials, particularly viziers, should be concerned with it. ${ }^{38}$ Narkh was practiced in all the lands of the Ottoman Empire, including the Balkans, from the earlier periods until the second half of the $19^{\text {th }}$ century. ${ }^{39}$

According to Mubahat Kütükoğlu, a well-known Ottoman historian, narkh for goods was determined in connection with two circumstances: usual and unusual. The former was practiced every season or twice a year, in some cases for certain goods only every few days. The latter was set only during an emergency, such as during wars or natural disasters, where the prices of goods usually increased. ${ }^{40}$

Determining the narkh for goods was generally the duty of regional or local $Q \bar{a} d \bar{l}$ s, although rarely, in this regard the Porte issued

38 In addition to this, some of the Ottoman scholars who discussed the subject of narkh in their works are as follows: Muverrih Âlî Mustafa Efendi in his Fusûsu'l-hall ve'l- akd ve usûlu'l-harc ve'n-nakd, Hezarfen Huseyin Efendi in both of his Tenkih-i Tevârih-i Mulûk and Telhîsu'l-beyân fì Kavânîn Âl-i Osman, and Sarı Mehmed Paşa in both of his Nesâyihu'l-vuzerâ ve'l-umerâ and Zubdei Vekayi'ât. For all those scholars and others, see Mübahat S. Kütükoğlu, Osmanlılarda Narh Müessesesi ve 1640 Tarihli Narh Defteri, pp. 4-8. In this regard, see also Mehmet Z. Pakalın, Osmanl Tarih Deyimleri ve Terimleri Sözlüğ̈̈, vol.: 2, 655-656.

39 Mehmet Z. Pakalın, Osmanlı Tarih Deyimleri ve Terimleri Sözlüğü, vol.: 2, p. 657; and Mübahat S. Kütükoğlu, "Osmanlı Iktisadî Yapısı", in Osmanli Devleti ve Medeniyeti Tarihi, ed. by Ekmeleddin Ihsanoğlu, vol.: 1, 564-565.

40 Mübahat S. Kütükoğlu, Osmanlılarda Narh Müessesesi ve 1640 Tarihli Narh Defteri, 9-12. 
fermâns. ${ }^{41}$ On some occasions if the guilds (esnâf) were not satisfied with the prices of certain goods that were set by the $Q \bar{a} d \bar{l}$ or there was a need to readjust them, they appealed to the court (or in some cases to the Porte) asking the $Q \bar{a} d \bar{\imath}$ to look into the matter. Then, the $Q \bar{a} d \vec{\imath} \mathrm{s}$ office would investigate, and if the complaint of the guilds were deemed justifiable then the $Q \bar{a} d \bar{\imath}$ readjusted prices. Otherwise, their complaint was rejected. ${ }^{42}$

Even though determining the narkh was the duty of the $Q \bar{a} d \bar{l}$, he usually did not fix it on his own. In this respect, the $Q \bar{a} d \bar{\imath}$ held regular meetings with reliable offices and associations in the city or town, who were involved with the issue directly or indirectly. After fixing the narkh for goods, the Qādis recorded the price-lists of goods that had been fixed in the sijils. In this regard, a large number of cases were recorded in the judicial records of Bitola. ${ }^{43}$ Price lists sometimes contained prices to a number of items for different type of goods, sometimes for a specific type of products. For instance, the narkh that was set on 26 December 1758 (25 Rabī' u'l-Ahar 1172) in the region of Bitola included several designated goods, such as meat, sugar, chickpeas, almonds, and soap. ${ }^{44}$ In another example, a narkh fixed during the 1790s in Bitola included a number of goods, like spices, coffee, fruits, wood, and charcoal. ${ }^{45}$ But the narkh fixed on the $26^{\text {th }}$ of June 1778 (25 Jumādiya'l-Awwal 1192) in Bitola included only meat and poultry. ${ }^{46}$

However, the most crucial point is how the $Q \bar{a} d \bar{l}$ determined the narkh, and what the normal measure was that he used in this regard. Since the aim of setting the narkh was to protect environment and to ensure prosperity among the people, both buyers and sellers, without loss or monopoly and unjust earnings, the $Q \bar{a} d \bar{l}$ fixed the prices of products only after having calculated the primary cost of a product

\footnotetext{
41 An example for a fermân that was issued by the Porte can be found in the judicial records of Bitola sijil: \#62-38a-1.

42 Ibid. For further details see also Mübahat S. Kütükoğlu, Osmanlılarda Narh Müessesesi ve 1640 Tarihli Narh Defteri, 12-13.

43 For instances, see the following sijils: \#54-27a-1; \#62-38a-1, 52a-5, 52a-8; \#6818b-2, 18b-4; \#69-2b-2; \#70-1b-1.

44 Sijil: \#54-27a-1.

45 Sijil: \#70-1b-1.

46 Sijil: \#62-52a-5.
} 
and its profit. Profit would not fall below $10 \%$ added to the actual cost and in some cases the profit would be as high as $20 \% .^{47}$

Despite the fact that the narkh for all products was fixed by the $Q \bar{a} d \bar{l}$, the control and inspection of their market prices, as mentioned earlier, was not done by him as this was the duty of the Muhtasib. A number of the judicial records of Bitola often clearly indicate this to be the case. At the order of the $Q \bar{a} d \bar{l}$, a Muhtasib had to control and inspect not only market products in general, but also their current price value set by the $Q \bar{a} d \bar{l}$. However, the Muhtasib had no right to fix the narkh or to approve a price for any product in the market without consulting the $Q \bar{a} d \bar{l}$. This aside, he was the most favored person for the $Q \bar{a} d \bar{\imath}$ with regard to the subject of narkh, since he was considered an expert of the market who knew the current prices of products very well and was always in contact with the guilds.

A study of the office of Muhtasib and the institution of narkh is important and would be very useful for the present day students and researchers interested in the history of cultures and civilizations, and particularly in social and economic history. Besides many other useful points, it provides a vast amount of information about the names and types of products and commodities that were to be found in the different regions throughout the Ottoman Empire. It also contains data and statistics of the prices of these products, which is indispensable for studies in the history of microeconomics for they furnish materials with regard to inflation and devaluation of currency in the Empire. Most importantly, the concern of Muhtasib in following the order and law with regard to not only prices of the products but the preservation of the environment and nature from consumerist minds and exploitations. This study attempted to show the awareness of the Ottoman Qadi in the Balkan region of Bitola whereby the major reference was Qadi's judicial records.

47 Mübahat S. Kütükoğlu, Osmanlılarda Narh Müessesesi ve 1640 Tarihli Narh Defteri, pp. 14-17. Idem, "Osmanlı Iktisadî Yapısı", in Osmanli Devleti ve Medeniyeti Tarihi, vol.: 1, 562. 


\section{CONCLUSION}

It is hoped that this article, which is based on various cases particularly related to environmental and gender issues, could lead to further researches as it further asserts that there is an urgent need to have a well organized regional studies on the Shari ${ }^{\prime} a h$ judicial records of the Muslim history as its geography covers the Afro-EuroAsian continents. In addition, by training the students and scholars in the field, this could possibly become a faculty discipline of its own in which, as a result, would help to enlighten individuals, institutions, business sectors, current legal practitioners and court judges on the applied ethics in the Ottoman legal system. 